\title{
Political Modernisation: The Rule of Law Perspective on Good Governance
}

\author{
Jan-Erik Lane \\ Charles Humbert, Geneva, Switzerland \\ Email: janeklane@gmail.com
}

Received 22 October 2014; revised 12 November 2014; accepted 8 December 2014

Copyright (C) 2015 by author and Scientific Research Publishing Inc.

This work is licensed under the Creative Commons Attribution International License (CC BY). http://creativecommons.org/licenses/by/4.0/

(c) $\underset{\text { EY }}{0}$ Open Access

\section{Abstract}

The United Nations, the WB as well as the IMF speak much of "good governance", but what is the meaning and reference of this elusive expression? In this paper, I will link it with the concept(s) of rule of law. Rule of law notions are spreading around the globe, being relevant for the transformation of monarchies and one-party states. Thus, world media are now reporting that for instance China's leadership is seriously debating making state reforms that would be conducive to more of the rule of law in the country. This is not be interpreted as a push towards western democracy. To clarify the relation between rule of law and competitive party democracy, this paper presents an enquiry into rule of law I and rule of law II. This distinction has a long history in political thought and constitutional developments. Data from the encompassing World Bank Governance project is used to validate these concepts referentially.

\section{Keywords}

Good Governance, Constitutional Law, Principal-Agent Model, Dimensions of Rule of Law: Rule of Law I, Rule of Law II, Democracy, World Bank Governance Project, Dimensions of Good Governance, Principal-Agent Theory of Politics and the State, Measuring Rule of Law von Mohl

\section{Introduction}

The rationale of constitutional rules or institutions is to be found in the restraining of political leaders in socalled principal-agent games that unfold constantly in politics and public administration. Constitutions are best viewed as institutional mechanisms, devised to constrain the behaviour of political elites. These mechanisms are man or woman made devices of rules that are put in place, and hopefully enforced to constrain activities, i.e. institutions. A mechanism consists of a combination of institutions that are constructed or evolve over time for the purpose of directing human actors towards outcomes. The mechanisms channel the behaviour of men and wom- 
en, affecting their preferences, objectives and interests.

The essence of rule of law institutions is to constrain the political agents-politicians at various levels of governments, political parties, rulers, bureaucrats, agencies, etc.- - to the advantage of the demos, i.e. the population in a country. Only rule of law institutions can restrain political agents from engaging in opportunistic behaviour, like e.g. corruption, favouritism, embezzlement or patronage or the employment of excessive force like torture and sudden disappearances or seizures.

\section{Constitutional Principles}

The doctrine of constitutionalism entails the idea of limited government. Moreover, limited government in relation to civil society implies a state that operates under certain key rules (Brazier, 1990; Bradley \& Ewing, 2010):

1) Legality: government is exercised by means of laws, enforced ultimately by an independent judiciary;

2) Lex superior: there is a higher law-the constitution-that guarantees certain rights for the citizens, like e.g. equality under the law, due process of law and habeas corpus;

3) Triaspolitica: executive, legislative and judicial powers are to be separated;

4) Accountability: governments can be held responsible for their actions and non-actions through various established procedures of criticism and complaint, enquiry and removal from office as well as redress;

5) Representation: the people have a SAY somehow in government through representative institutions.

These principles above emerged hundreds of years ago, long before democracy was introduced in many countries at the end of the First World War in Europe and America (Lloyd, 1991a; Lloyd, 1991b; McIlwain, 1958; Neumann, 1986). Today all existing democracies endorse these constitutional principles: constitutional democracies. But several non-democratic countries honour principles of the rule of law without accepting Western style democracy. Thus, rule of law is relevant to both democratic and non-democratic regimes.

One encounters the principles of rule of law above in various forms through history, either a few of them or all five (Burns \& Goldie, 1991; Wormuth, 1949; Pennock \& Chapman, 1979; Jowell, 1994; Jowell \& Oliver, 1994). They are to be found long before the democratic regime was theorized thoroughly by Spinoza and Rousseau and it was practised in some countries with Common Law without democracy and in other countries in the form of the German Rechtsstaat (Reiss, 1970; Riley, 1983). Kant (1974) advocated rule of law, but he was not a democrat, endorsing constitutional monarchy, underling legality and due process of law more that representation and popular accountability. The political scientist von Mohl (1832) was an exception in Germany, combining all five principles above. Today, the rule of law principles $1-5$ are relevant to all kinds of political regimes in the world.

Constitutional government embodies institutions or rules that constrain those active in domestic or international politics today. Thus, the meaning of "constitution" is a set of principles or rules that constrain rulers, politicians, governments or states. But there can be constitutional government without Western democracy, based upon competitive elections among political parties. Let me explain the distinction between two key concepts in good governance: rule of law I (legal integrity, judicial autonomy) and rule of law II (competitive party government), as they refer to good governance, according to the World Bank approach in its Governance project.

\section{Rule of Law I and II}

The concept of good governance has no standard definition in the dictionaries. Instead, I will rely upon the approach of the World Bank project to governance. The World Bank (WB) states:

"Governance consists of the traditions and institutions by which authority in a country is exercised. This includes the process by which governments are selected, monitored and replaced; the capacity of the government to effectively formulate and implement sound policies; and the respect of citizens and the state for the institutions that govern economic and social interactions among them".

http://info.worldbank.org/governance/wgi/index.asp

The World Bank's Worldwide Governance project, mapping good or bad governance around the globe during the last decade, identifies six dimensions in of the concept introduced in the quotation above.

In the World Bank Governance project, one encounters the following definition of "rule of law":

Rule of law $(\mathrm{RL})=$ capturing perceptions of the extent to which agents have confidence in and abide by the rules of society, and in particular the quality of contract enforcement, property rights, the police, and the 
courts, as well as the likelihood of crime and violence (Kaufmann, Kraay, \& Mastruzzi, 2010: p. 4).

Rule of law (RL) is explicitly separated from voice and accountability (VA), which is defined as follows in the World Bank project thusly:

Voice and Accountability $(\mathrm{VA})=$ capturing perceptions of the extent to which a country's citizens are able to participate in selecting their government, as well as freedom of expression, freedom of association, and a free media (Kaufmann, Kraay, \& Mastruzzi, 2010: p. 4).

The World Bank Governance project suggests four additional dimensions of good governance (political stability, government effectiveness, regulatory quality, and the control of corruption). The World Bank Governance project employs a host of indicators in order to measure the occurrence of rule of law RL around the globe, which results in a scale from -3 to +3 .

In a constitutional democracy, there is a combination of both rule of law (RL) and voice and accountability (VA). But rule of law was conceived already in the Ancient and medieval periods, whereas Western type democracy belongs to the 20th century. Thus, I will separate between a narrow concept of role of law I, corresponding to the World Bank's terminology, and rule of law in a broad concept, as including voice and accountability (VA). Several countries have or may introduce rule of law I without accepting rule of law II, i.e. party competitive democracy.

Rule of law principles offer mechanisms that restrain behaviour. We distinguish between rule of law in a narrow sense (legality, due process) - rule of law I-and in a broad sense-rule of law II (constitutional democracy). Some countries practice only rule of law I, whereas other countries harbour both mechanisms. A few countries have neither rule of law I or rule of law II, especially failed or rogue states or states in anarchy or anomie. Let us consider how China is ranked in the World Bank Governance project.

Figure 1 shows the overall country picture with rule of Law II on the x-axis (voice and accountability) and rule of Law I on the y-axis (legality and judicial autonomy).

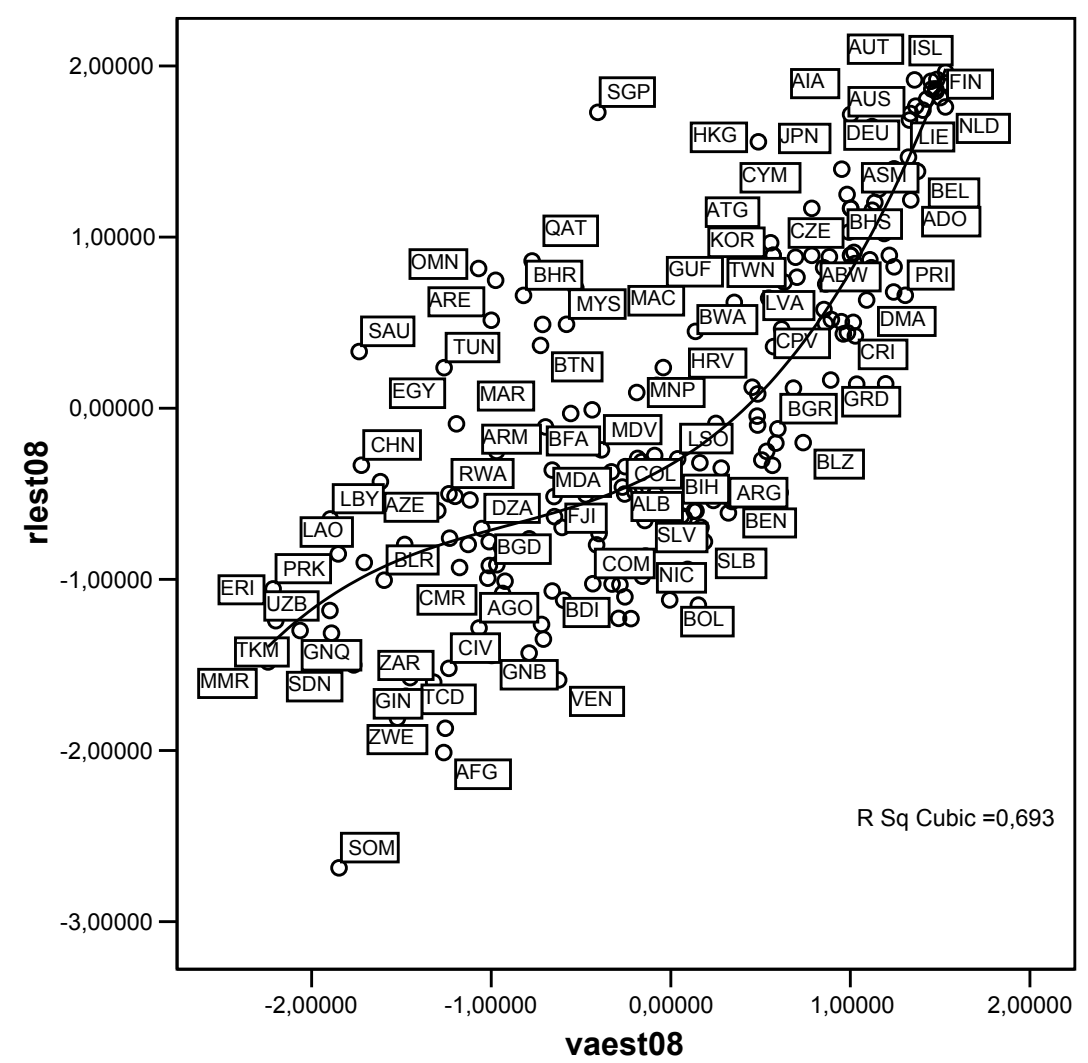

Source: Governance Matters 2009. Worldwide Governance Indicators 1996-2008: vaest08, rlest08.

Figure 1. Rule of law I (rlest08) and rule of law II (vaest08). 
In general, the occurrence of rule of law II is a sufficient condition for the existence of rule of law I. But rule of law I-legality and judicial independence-is only a necessary condition for rule of law II-constitutionalism as voice and accountability, according to Figure 1. The largest state on the Earth-China (CHN)—scores low on rule of law II and 0 on rule of law I, whereas the tiny city-state of Singapore (SNG) ranks high on rule of law I and medium on rule of law II. Why, then, would reforms in China towards better rule of law I be important for both the people of the country and international relation?

Figure 1 calls attention to the relevance of the distinction between rule of law I and rule of law II. Several countries in the world satisfy rule of law I requirements without scoring high on the rule of law II requirements. Improving rule of law I with for instance the Ombudsman Office would matter much in many countries, even though they are not democracies, according to rule of law II criteria.

\section{Why Rule of Law I or II: What Is the Basic Rationale?}

There is a form of interaction that tends to be long-term between individuals, which involves a hiatus between the agreement about what is to be done against remuneration (ex ante) and the later in time fulfillment of this contract (ex post). This time interval, lasting often more than several months or years, sets up the monitoring problem: Has the agreement been fulfilled in accordance with the considerations when the contract was made? This type of interaction does not take place in the various market forms, but constitutes a problem of analysis in itself (Arrow, 1985). The more this special type of contracting was analysed, between a principal asking for a service or job on the one hand and a set of knowable agents delivering this service or job on a long-term contract, the more often it was found in various important sectors (Ross, 1973; Grossman \& Hart, 1983; Sappington, 1991; White, 1992; Ackere, 1993; Althaus, 1997). What came to the known as "the principal's problem" was found in lengthy interactions within legal affairs, psychiatry, sock-market trading and agricultural production (sharecropping).

Two basic aspects of long-term contracting are transaction costs and asymmetric information, which never entered in the standard assumptions of the neo-classical decision model in mainstream economics. Since the agent(s) is supposed have much more knowledge about the service or job to be done, the principal needs to diminish this advantage, but without running up too heavy transaction costs, through costly monitoring or litigation. The agent(s) wants remuneration, which has to come from the value of the service or job delivered. Thus, there is both cooperation and conflict. In politics, one may model two principal-agent games, one game for moral hazard focusing upon good or bad performance after the election and another game for adverse selection or the choice of good or bad politicians before the election.

The theory of transaction costs stimulated this way of looking at long-term contracting (Rao, 2002). It was also furthered by insights into the nature of institutions, where rules could be employed to prop up the position of the principal (Furubotn \& Richter, 2005; Weingast, 1989; Persson \& Tabellini, 2003). However, the public choice school contributed little to the theory) of principal and agents (Breton, 2007; Mueller, 2003), focusing almost exclusively on rent-seeking. Now, rule of law is nothing less than the regime that hands down institutions that counter-act agent opportunism, bolstering the principal.

\section{Principal-Agent Interaction in Politics}

In well-ordered societies, the political agents in government operate the set of governance mechanisms that we call "state" (Kelsen, 1961; 1967). It claims sovereignty over its country, but it enters into a web of relationships with other states, governed by the rule of law principles of the international society, namely the so-called public international law (Schwöbel, 2011).

A state or government may be seen as flowing from an agreement among the members about helping each other in securing peace and stability. A body of rules would codify this mutual agreement. A political club quickly develops a division of labour between leaders and followers, the subgroup who implements the rules and the subgroup who follow the rules in their behaviour. I will call the followers the "principal" of the political club and the leaders the "agents". Thus, the political club will be modelled as confronted by the principal-agent problematic, comprising inter alia:

- Who are the political agents?

- How are these agents selected?

- Can agent power be laid down formally? 
- Are there restraints on the power of the agents?

The principal-agent framework has enjoyed farreaching success in modelling interaction between persons where one works for the other. This interaction is to be found in many settings, such as agriculture, health care, insurance and client-lawyer (Rees, 1985; Laffont \& Martimort, 2002). As a matter of fact, the principal-agent problematic is inherent in any employment relationship where one person works for another, who pays this person by means of the value of the output.

Whenever people contract with others about getting something done, there arise the typical principal-agent questions:

1) What is the quid pro quo between the principal and the agent?

2) How can the principal check the agent with regard to their agreement?

3) Who benefits the most from the interaction between principal and agent?

These questions concerning principal-agent interacting arise whenever there is a long-term contract between two groups of people, involving the delivery of an output against remuneration as well as a time span between the making of the contract and the ending of the relationship with the delivery of the output. One finds this type of interaction in the client-lawyer relationship in the legal context, in the owner-tenant interaction in sharecropping as well as in the asset holder-broker relation in financial markets.

In politics, transaction costs are minimised by handing over the responsibility for the tasks of the political club to a set of people, called the leaders. I will employ the word: "agents". The agents provide the members of the political system-the principal—with the chief goods and services of this type of community, when they are successful that is.

The agents and the principal are the two key components of political interaction that run through all political systems, whatever their nature may be. The problem of institutionalising the polity originates in this opposition between agents and the principal.

When governance is modelled as a principal-agent game, then it is not merely a matter of the interaction between two or more persons. The agent(s) is hired to accomplish an output or outcome, to be paid for his/her effort to do so. Here we have the two key foci in a principal-agent evaluation of governance: 1) the achievements-good or bad performance; 2) the remuneration-high or low.

In the literature, these two aspects-performance and remuneration-are not always kept separate. Thus, one speaks of bad performances when there is only high remuneration like in "corruption" or "rent-seeking". Moreover, bad performance is sometimes equated merely with a failure to live up to promises made. The principalagent framework is applicable to governance even when there is no form of embezzlement by the agent or merely reneging on lofty promises.

\section{Agents' Opportunism}

Political agents are no different from any other human beings. They are driven by the same mixture of egoism and altruism as the average person. Sometimes political agents may be completely obsessed by protecting their own self-interests, as with cruel personalities like Genghis-Khan, Tamerlane, Hitler and Stalin. Sometimes political agents display great generosity and forgiveness towards their opponents, like Gandhi and Mandela. But on average political agents would be self-seeking, often with guile-the opportunism assumption.

The implications of assuming opportunism on the part of agents are strengthened in terms of importance when one adds the basic fact about long-term interaction of the principal-agent type, namely asymmetric information. It is the agent who delivers the output who knows the most about all things relevant to the interaction. And the agent will use this information advantage to capture a rent, or a set of benefits.

Strategy is a pervasive trait of human interaction, both in the micro setting and in the macro setting. Taking strategic considerations into account goes well in hand with opportunism and asymmetric information. The same applies to tactics. What, then, is the basic issue of contention in the principal-agent interaction? Answer: the division of advantages, given a certain size of the mutual gains to be had.

\subsection{The Production of Value and Its Distribution}

Political clubs help the population produce an output, a set of goods and services, to be denoted here with "V", meaning value. By providing peace and stability, the population may engage in productive labour, resulting in an output of increasing value year after year. The political agents will claim a part of this value $\mathrm{V}$ for their contribu- 
tions. It is the principal who ultimately has to pay the agents out of the total value $\mathrm{V}$ in society.

The agreement about what the agents are to contribute with as well as what they are to be paid may be only a tacit one. It may not even be a voluntary one, as the political agents may force the principal to accept an agreement by the employment of force.

Two things are of major concern to the principal:

1) The maximisation of $\mathrm{V}$ : If the political agents act in such a manner as to reduce $V$, then this is not in the interest of the principal;

2) Reasonable agent remuneration R: If the agents manage to capture a considerable portion of $V$ for themselves, then that would be counterproductive to the principal.

It follows from these two principles that principals would be very unhappy with a situation where their political agents contribute to a low output $\mathrm{V}$, while at the same time providing them with a considerable share of $\mathrm{V}$ by maximising $\mathrm{R}$.

What is included in the output V? One may offer a most comprehensive definition of V, denoting both tangible assets and intangible ones? $\mathrm{V}$ includes all things that are valuable government and its members: goods, premises, services, assets, perks, prestige, esteem, etc. Or one may confine $\mathrm{V}$ to the set of public or semi-public goods. The political club contracts with a set of agents in order to protect $\mathrm{V}$, but the principal must remunerate the agents (R) from V. How can the principal select and monitor its agents so that $\mathrm{V}$ is maximised, given the constraint that the set of agents must be compensated for their effort from $\mathrm{V}$ ?

The interaction between political leaders and the population is omnipresent. Whatever the leaders are called and whichever rules apply for their behaviour, human societies have not been leaderless. Even among groups with a highly egalitarian culture, political leaders somehow emerge. This sets up the principal-agent problematic inherent in government. It is to be found in all levels of goernment whatever the form of institutionalisation.

When two people or sets of people interact, they may arrive at a mutual understanding of the terms of interaction. These expectations may be enshrined in a contract, written or verbal. Yet, even when the expectations governing the interaction between the political agents and the principal are not codified somehow, there is still consideration.

Consideration is at the core of human exchange and contracting: Something of value is given for getting something from another person. Consideration is the inducement, price or motive that causes a party to enter into an agreement or contract. In politics, the leaders receive ample consideration for governing the country. They take a part of total value $\mathrm{V}$ for their needs. And they are expected to deliver services to the political club, first and foremost maintain the peace.

The concept of consideration is a broad one, covering any compensation paid, or all inconvenience suffered by the party from whom it proceeds. A consideration of some sort or other is essential to the forming a reasonable contract. A nudumpactum would be an agreement to do or to pay anything on one side without any compensation to the other. In ordinary law no one can be compelled to fulfil a nudumpactum, but in politics absolutist rulerships and dictatorships are essentially just that.

Since the consideration must be some benefit to the party by whom the promise is made, or to a third person at his instance, or some detriment sustained at the instance of the party promising by the party in whose favour the promise is made, politics is replete with consideration. The agents of the political clubs employ a variety of techniques to raise value to themselves as consideration for their governance activities.

In respect of time, a consideration may be executed, or something done before the making of the obligor's promise. In modern law, an executed consideration is insufficient to support a contract but an executed consideration on request or by some previous duty is sufficient to maintain an action. In politics, consideration is omnipresent, although institutionalised to various degrees. The principal holds the agents responsible for the major developments, and it furnishes the agents with the resources necessary to direct government, whether voluntarily or involuntarily.

\subsection{Key Forms of Consideration in Political Contracts}

In government, the interaction between the agents and the principal varies depending upon the consideration implicit in the contract between them. It is an open question who prevails of the two parties. Thus, logically one may separate between two alternative considerations, or ideal-type structures at the extreme poles:

Subjugation of the principal: In this extreme principal-agent relationship, the principal is reduced to slavery or 
serfdom, the agents exercising total domination-oriental despotism, totalitarian state. Yet, there is still consideration, as the enslaved population handles in a huge part of the yearly production to the agents, to be employed for governance. Typically, when the grip of the agents over the population slips, then there may occur rebellions, the principal searching for new agents.

Rule of law constraint over the agents: In the opposite extreme type, the political agents are checked by a variety of mechanisms so that they cannot accede to a position of dominance over the principal, like in intense direct democracy plus the popular initiative (Swiss democracy) as well as the recall of agents and imperative mandate (trade union democracy).

\subsection{On the Risk of Political Monopoly and Looting}

The external costs to principal may be very high, if there is political monopoly. What the principal would not want to have, all other tings equal, is a situation where the political agents not only take a huge remuneration $\mathrm{R}$ for their work but also accomplish mediocre or straightforward disastrous outcomes, reducing the value of society V. In the principal-agent literature, excessive remuneration on the part of the agent is referred to as "rentseeking", whereas the failure of the agents to deliver on what they have promised is called "dissonant" actions. The important point here is that political agents may disappoint their principal on two grounds: 1) Dissipation of value V, meaning underperformance as measured by outcomes; 2) Looting, i.e. engaging in excessive remuneration R.

A virtue of the principal-agent perspective is that it alerts people to the possibility of large-scale looting in politics. The worst case scenario for the principal is the combination of bad outcomes in politics and excessive remuneration for agents responsible for the results. This happens often when there is looting.

"Looting" refers to any form of taking of value that amounts to an un-proportional compensation in relation to the effort exerted. It may be illegal, as when soldiers go on a rampage. But political looting is often more refined than populist looting when law and order breaks down. The appropriation of the resources of the administrative apparatus ("slack") is a typical form of political looting, much emphasized by Weber for his comparative institutional analyses (Weber, 1978). The concept of political looting is broader than the notion of corruption or embezzlement, which are strictly illegal phenomena.

Looting may occur with or without value dissipation. Political agents may successfully claim a huge portion of the value in society without at the same time reducing the total size of value. In many Third World countries, political looting goes hand in hand with value dissipation though. An extreme case is that of present day Zimbabwe, which country according to its president "is mine".

During known human history, there have occurred a wide variety of forms of looting. One may mention the Pharaohs, who treated the entire country as their "oikos" or household. Mohammed sanctioned looting with a religious argument in order to favour a rapid expansion of the Arab Empire. Looting constituted a key issue in Western feudalism, as the lord and the vassal focused upon how the fruits from the various benefices and fiefs were to be divided, both in the short-run and the long-run perspective. Finally, massive looting occurred in the authoritarian regimes of the 20th century, where both fascist and communist leaders looked upon politics as booty, covering embezzlement, patronage and favouritism.

Sophisticated forms of looting may occur in constitutional democracy, as when the executive allows itself to be surrounded by vast staff of advisors, experts and the like. Or political agents in the legislature manage to provide themselves with excessive budgets and perks. The fact that corruption allegation is an almost constant theme in public debate indicates how sensitive the principal is to the risk of looting. One form of political looting is of course nepotism or favouritism with regard to family members or cliques of friends when conducted by a president or premier for instance. Petty forms of looting involve negligence about the line of separation between private and public expenditures.

The rule of law regime is highly aware of the risk of looting, offering restraining rules about taxation, budgeting and financial accountability. It also aims at counteracting the dissipation of social value through representation, election and re-election. The dissipation of value is a problem of aggregation in society (size of the cake), whereas the risk of political looting presents a distributional problem (who gets what).

\subsection{On the Risk of Value Dissipation}

The constant focus of policy-makers upon economic growth shows how aware the principal is today about the 
risk of value dissipation. The population worries not only about various forms of looting but also about the risk of unfortunate or disastrous policy-making that reduce aggregate income or wealth. A set of political agents may be extremely costly to the country because they are incompetent although honest. Political consideration as defining the quid pro quo relation underneath political leadership would comprise some mechanism for replacing one set of agents with another, especially in a rule of law regime.

There is the possibility of a dramatic effect from the combination of looting and dissipation of value, like for instance as matters now stand in countries like Myanmar, Zimbabwe and North Korea. One should not, however, assume that the risk of value dissipation is unique to Third World countries. On the contrary, value dissipation occurs also in First World countries, where the 2003 American led invasion of Iraq offers a telling example, resulting in so huge costs-human and economic - and so little value. And even a country like the UK with its rule of law tradition does not appear to be immune from various looting strategies on the part of parliamentarians, definitely immoral but not always illegal.

\subsection{Variety of Principal-Agent Models in Politics}

Whether in models of private companies or of the bureaucracy, principal-agent interaction harbours games between two or more players that involve both cooperation and conflict. Generally speaking, the principal may pay high or low remuneration for the effort of the agent(s). And the agent(s) may deliver high or low effort. Thus arise the problematic of offering and monitoring a contract with the agent(s) that elicits the best outcome for the principal, meaning high effort and reasonable remuneration to the agent(s) (Rasmusen, 2006).

The basic principal-agent model above has been developed in various elaborate ways in order to account for elections and re-elections in democracies (Barro, 1973; Besley, 2006; Helland \& Sörensen, 2009). In a general analysis of politics in well-ordered societies or in countries with kleptocracy, the principal-agent approach high lightens two problematic in governance: 1) value dissipation (poor performance); 2) looting (excessive remuneration).

Political agency of whatever kind it may be is fundamentally a job that has to get done against remuneration. This approach to political agency underlines its costs in the quid pro quo: What is the agent to do against what pay? Political agency is heavily institutionalized, as the population as principal wishes to restrict the behaviour of the agents-politicians, bureaucrats, legislators and judges. However, the institutions define the degrees of freedom, but they do not solve the incentive problem: How to motivate the agents to try hard to promote the interests of the principal?

Political costs arise with any form of political agency, as the politicians or political parties will not simply implement the policies the electorate wants without remuneration. The question of the size and nature of this remuneration has become a key issue in the post-modern society where political ideologies motivate less. There are a few key models of this effort-remuneration problematic in politics, stated in terms of the principal-agent approach. Let me briefly mention them in order to pinpoint these model differences concerning how agency costs are conceived:

1) Costs as embezzlement (Helland \& Sörensen, 2009);

2) Costs as campaign funds (PAC:s) (Barro, 1973);

3) Costs as pursuing agent's own preferences (Besley, 2006);

4) Costs as bad performance like real policy failure (Ferejohn, 1986; Ferejohn \& Shipa, 1990).

Groups in the electorate vote for a political party-a set of politicians with a common strategy-in order to have them promote a set of policies by means of outcomes-good performance. Due to the gap between election dates-normally four years, the relationship between the principal and the politicians he/she elects becomes one of asymmetric information, where effort is non-observable and non-verifiable. The politicians have normal incentives, meaning they wish to get paid somehow-maximum perquisites or at least much of them.

Political agency is a game with two rounds of play: election and re-election. Only re-election offers a strong restraint upon the agents not to "shirk", meaning renege upon the effort to promote the interests of the principal. Only re-election gives the principal the opportunity to get rid of an agent who really was not a good one from the beginning (a "lemon").

The theory of political agency as embezzlement is not really a success. Although corruption may be rampant in several Third World countries and flare up in spectacular cases in a few well-ordered societies like e.g. the UK, political agents do not employ such blunt tactics as stealing public money. Helland and Sorensen claim that 
the threat of embezzlement is a most powerful one, forcing the principal to pay a rent to the agents. This is wrong. Bad agents who embezzle cannot survive the re-election stage, when asymmetric information is corrected.

The theory about agency costs as the extra campaign funds besides normal politician salary fits US democracy well. It models a structural weakness in the US political system, because these extra payments from pressure groups will only be forthcoming when politicians deliver policies, regulations or contracts as reciprocity. This always comes with an extra cost to the economy, involving the risk for social inefficiencies and massive rent seeking costs depleting the rents acquired. However, in other democracies the system of PAC:s is not allowed. In addition, the Barro model presents the difficulty of one agent serving two principals with opposite interests to some extent.

The Besley model is more applicable onto European democracies. It posits a radical separation between good and bad politicians, the latter being leaders or parties that promote their own policy agenda at the detriment of their policy promises to their principals. Given replay, the principal can eliminate bad politicians in the re-election. But under what conditions will a bad politician push his/her agenda already in the first round of play? Bad politicians could mimic good politicians in at least two rounds of play, surviving the re-election test. Under the Besley model, a lame duck politician would always push his/her policy agenda because there are no more rounds of play. Pushing one's own agenda is lick scoring a rent. Thus, also good politicians will be tempted.

The distinction between good and bad politicians has a moralistic ring to it, which makes it less useful in scientific research. Is a bad politician an embezzler, a lackey of pressure groups or merely an idealistic loner who pushes his/her own convictions? Political agents tend to have their own agendas and the institution of representative democracy places few restrictions upon the mandate. Why would the principal not re-elect an agent who accomplishes positive outcomes by following his/her own agenda?

One may conceptualise the difficulties in governing as two games of principal-agent interaction, comprising two different forms of asymmetric information. In politics, the principal is confronted with the problem of voting for politicians or political parties agents at one election e1. But the voter as principal does not know whether the agents will really deliver-ex post the election-high performance although promising to do so (moral hazard). The voter dos not even have-ex ante the election-full information whether the agents are capable of high performance (adverse selection). When the voter is not pleased with his/her agent, then he or she can decide to vote for another agent in the next coming election e2. Thus, the principal-agent games in politics have two rounds of play.

The principal would be willing to re-elect an agent who delivers high performance but reject the agent who delivers low performance (incentive compatibility). The risk in politics is that the agents promise one thing but delivers the opposite. Only eternal vigilance on the part of the principal in checking the political agents can improve upon the probability of the best outcome for the principal, given that few agents are benevolent saints. The worst outcome conceivable is that the agents deliver poor results but demands excessive remuneration. In the worst-case scenario, the agent appropriates much value produced in a country, or at least a considerable part of it (looting). In any case, the principal must pay the agent a level of remuneration that he/she could receive elsewhere (participation constraint).

To sum up: It appears from Figure 2 that a majority of the population on the Earth do not enjoy the combined benefits of rule of law I and rule of law II. Actually, large portions of the peoples of the world do not even live under rule of law I in their daily lives, like mainland China.

Figure 2 shows clearly that there is ample room for improvements in rule of law I in several populous states, even if they for various reasons do not endorse rule of law II, or Western democracy.

\section{Good Governance: Transparency and Effectiveness}

It has been pointed out that the expression "goog governance" has received numerous of definitions, some focusing upon the processes of decision-making whereas others have targeted outcomes or results, such as happiness or well-being. When one is confronted by semantic ambiguity or multiplicity of meanings, one research strategy is to enquire into how various concepts linked with the term or expression relate to each other referentially. This is often a more informative strategy that attempting to find the common core in all the various definition, or declare a new stipulative definition like good governance as impartiality (what is an impartial policy mix by government). 


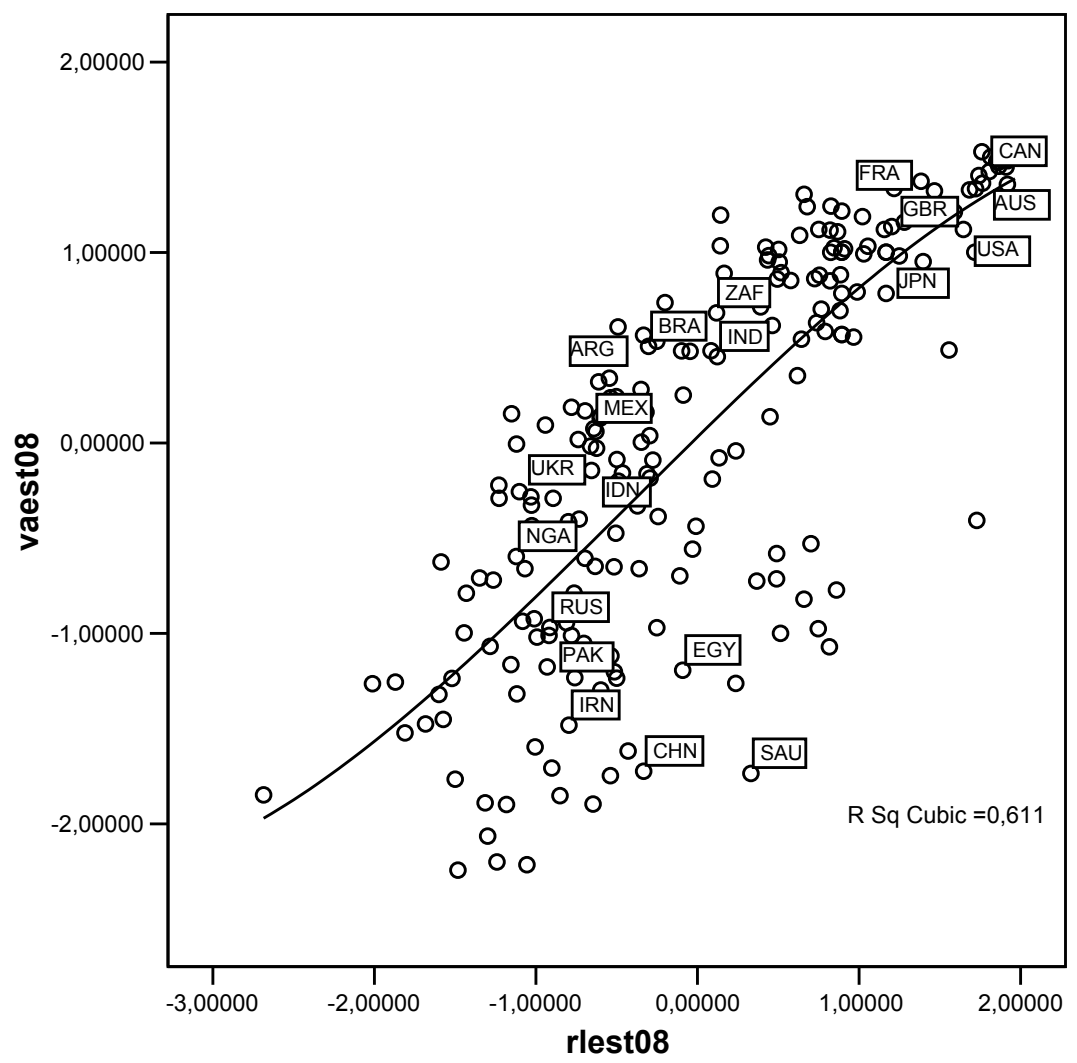

Source: Governance Matters 2009. Worldwide Governance Indicators 1996-2008: vaest08, rlest08.

Figure 2. Rule of law I and II in big states ( $>10$ million inhabitants).

Thus, Figure 3 looks at the relationship between rule of law I and the absence of corruption as transparency in the World Bank Governance project.

Figure 3 provides strong evidence that the institutionalisation or legal integrity and judicial autonomy is conducive to the control of corrupt behaviour or practices. China actually scores better on both indices than Russia or Nigeria, but far from the scores of UAE, Japan and Singapore. Rule of law I is clearly relevant for good governance in countries that have other political systems that Western democracy.

Governmental effectiveness is considered by the World Bank Governance Project as a vital aspect of good governance. Figure 4 shows again that countries may score high on this aspect of good governance without scoring high on rule of law II.

The general trend is though those countries with rule of law II tend to score high on the index of governmental effectiveness.

\section{Conclusion}

A political regime that runs according to rule of law would satisfy a few conditions that constrain the exercise of political power (Vile, 1967; Tierney, 1982). Rule of law entails that power is be exercised according to the following precepts concerning due legal process and judicial accountability:

1) Legality (nullum crimen sine lege);

2) Constitutionality (lex superior);

3) Rights and duties: negative human rights (habeas corpus);

4) Judicial independence: complaint, appeal and compensation.

The theory of good governance entails that a government adhering to these precepts will be more successful in enhancing socio-economic development than a government that fails to respect these principles. Thus, economic activity will be stimulated by legal predictability, the protection of property and the autonomy of judges when testing cases for assumed violations of legality or constitutionality (Cooter \& Ulen, 2011). 


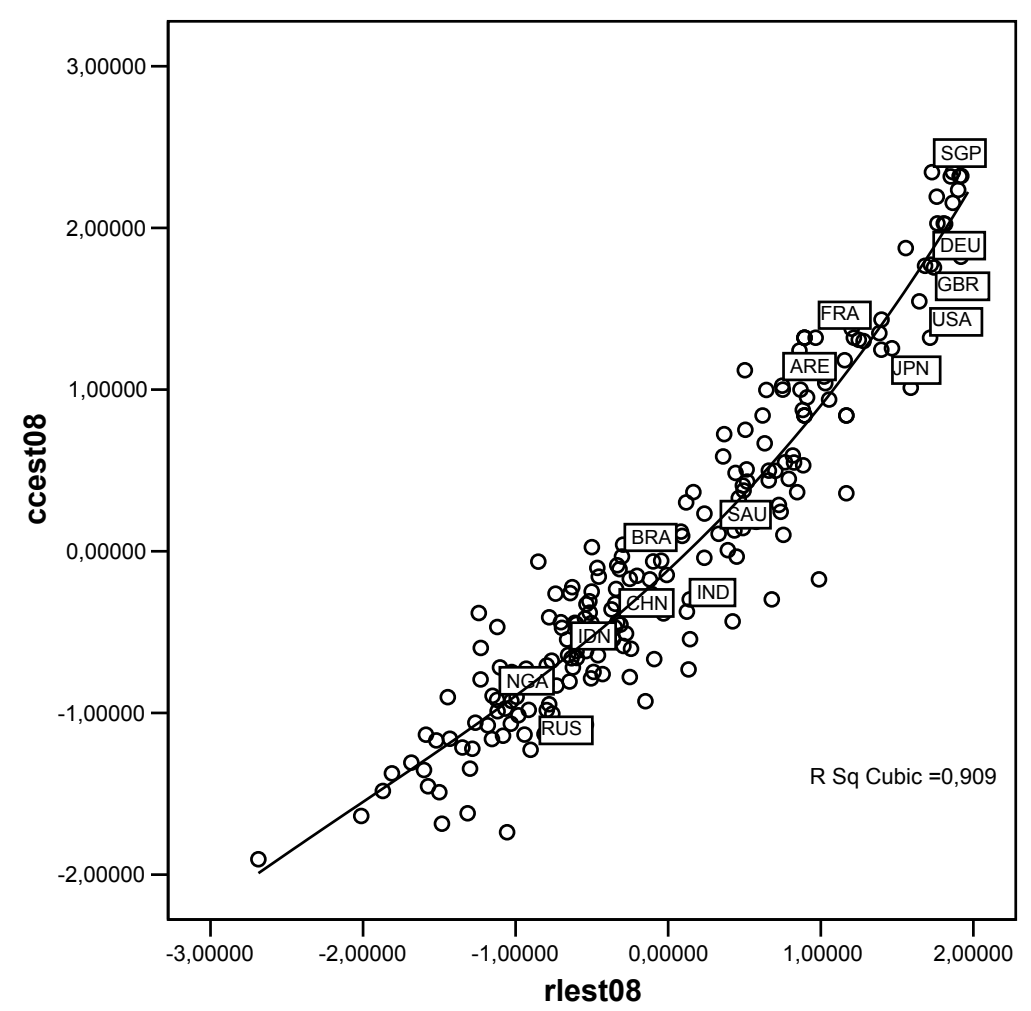

Source: Governance Matters 2009. Worldwide Governance Indicators 1996-2008: rlest08, ccest08.

Figure 3. Rule of law I and transparency (control of corruption).

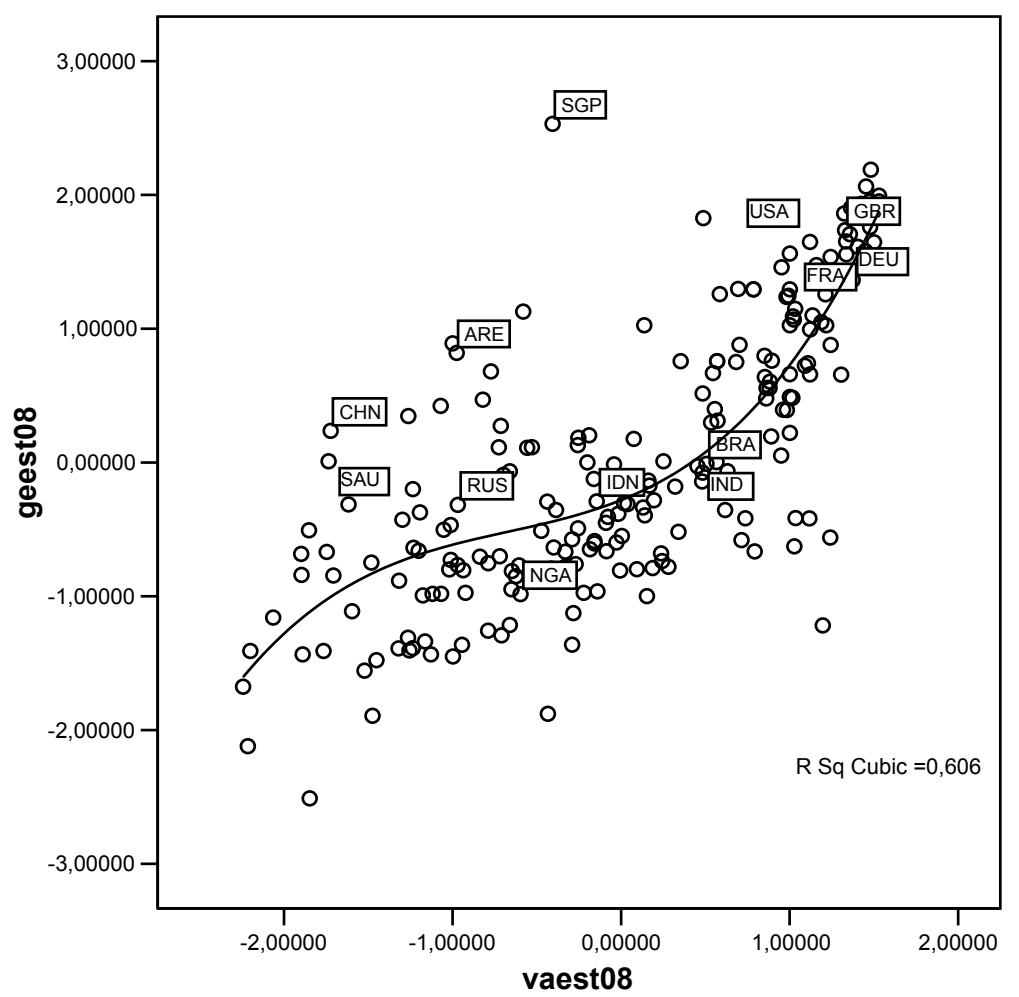

Source: Governance Matters 2009. Worldwide Governance Indicators 1996-2008: vaest08, geest08.

Figure 4. Rule of law II and government effectiveness. 
From the rule of law perspective, two unresolved questions are central in political agency, whatever the political regime may be:

1) What is the proper remuneration of the agents, both salary and perks?

2) Do agents really deliver, i.e. how can agent performance be evaluated systematically in terms of outcome data?

The remuneration of political agents, whether in legal or illegal forms, has not been much researched, not even in democracies where information is in principle available. For countries where the state controls such information not much is known, for instance about China. However, it is a well-known fact that political agents in some countries engage in comprehensive looting, for instance in Myanmar. The theme of corruption is a most important aspect in a principal-agent model of the interaction between people and political agents. Yet, there are several forms of corruption that need to be studied separately. Somehow the perspective of corruption does not offer a broad enough view of the entire remuneration question. See Meredith (1997) for an inventory of all forms of opportunism by politicians and officials in Africa to capture a rent or dissipate value.

\section{References}

Ackere, A. (1993) The Principal/Agent Paradigm: Its Relevance to Various Functional Fields. European Journal of Operational Research, 70, 83-103.

Althaus, C. (1997) The Application of Agency Theory to Public Sector Management. In G. Davis, B. Sullivan, \& A. Yeatman (Eds.), The New Contractualism (pp. 137-153). Melbourne: Macmillan.

Arrow, K. (1985) The Economics of Agency. In J. Pratt, \& R. Zeckhauser (Eds.), Principals and Agents: The Structure of Business (pp. 37-51). Cambridge, MASS: Harvard University Press.

Barro, R. J. (1973) The Control of Politicians: An Economic Model. Public Choice, 14, 19-42.

Besley, T. (2006) Principled Agents? The Political Economy of Good Government. Oxford: Oxford U.P.

Brazier, R. (1990) Constitutional and Administrative Law. London: Penguin Books.

Burns, J. H., \& Goldie, M. (Eds.) (1991) The Cambridge History of Political Thought (pp.1450-1700). New York: Cambridge University Press.

Cooter, R. D., \& Ulen, T. (2011) Law and Economics. New York: Pearson.

Ferejohn, J. (1986) Incumbent Performance and Electoral Control. Public Choice, 30, 5-25.

Ferejohn, J., \& Shipa, C. (1990) Congressional Influence on Bureaucracy. Journal of Law, Economics, and Organization 6 , $1-20$.

Furubotn, E. G., \& Richter, R. (2005). Institutions and Economic Theory: The Contribution of the New Institutional Economics. Ann Arbor, MI: The University of Michigan Press.

Grossman, S. J., \& Hart, O. D. (1983). An Analysis of the Principal-Agent Problem. Econometrica, 51, 7-46. http://dx.doi.org/10.2307/1912246

Helland, L., \& Sörensen, R. J. (2009). Hvorforoverleverpolitiskkorrupsjon i representative demokratier. Norsk Statsvitenskapelig Tidsskrift, 25, 219-236.

Jowell, J. (1994). The Rule of Law Today. In Jowell and Oliver, op.cit., 57-78.

Jowell, J., \& Oliver, D. (Eds.) (1994). The Changing Constitution. Oxford: Clarendon Press.

Kant, I. (1974). The Philosophy of Law. Clifton, NJ: Augustus M. Kelley.

Kaufmann, D., Kraay, A., \& Mastruzzi, M. (2010). The Worldwide Governance Indicators: Methodology and Analytical Issues. World Bank Policy Working Paper No. 5430.

Kelsen, H. (1961). General Theory of Law and State. New York: Russell \& Russell.

Kelsen, H. (1967). Pure Theory of Law. Berkeley, CA: University of California Press.

Laffont, J. J., \& Martimort, D. (2002). The Theory of Incentives: The Principal-Agent Model. Princeton, NJ: Princeton University Press.

Lloyd, D. (1991a). The Idea of Law. London: Penguin Books.

Lloyd, H. A. (1991b). “Constitutionalism”. In Burns and Goldie. op.cit., 254-297.

McIlwain, C. H. (1958). Constitutionalism, Ancient and Modern. Ithaca: Cornell University Press.

Meredith, M. (1997). The State of Africa. London: Free Press.

Neumann, F. L. (1986). The Rule of Law: Political Theory and the Legal System in Modern Society. Berg: Leamington Spa. 
Pennock, J. R., \& Chapman, J. W. (Eds.) (1979). Constitutionalism. New York: New York University Press.

Persson, T., \& Tabellini, G. (2003). The Economic Effects of Constitutions. Cambridge, MA: MIT Press.

Rao, P. K. (2002). The Economics of Transaction Costs. Basingstoke: Palgrave/Macmillan. http://dx.doi.org/10.1057/9780230597686

Rasmusen, E. (2006). Games and Information: An Introduction to Game Theory. Oxford: Blackwell.

Rees, R. (1985). The Theory of Principal and Agent. Bulletin of Economic Research, 37, 3-26. http://dx.doi.org/10.1111/j.1467-8586.1985.tb00179.x

Reiss, H. (Ed.) (1970). Kant's Political Writings. Cambridge: Cambridge University Press.

Riley, P. (1983). Kant's Political Philosophy. Totowa, NJ: Rowman \& Allanheld Publishers.

Ross, S. A. (1973). The Economic Theory of Agency: The Principal's Problem. American Economic Review, 63, $134-139$.

Sappington, D. (1991). Incentives in Principal Agent Relationships. Journal of Economic Perspectives, 3, 45-66. http://dx.doi.org/10.1257/jep.5.2.45

Schwöbel, C. E. J. (2011). Global Constitutionalism in International Legal Perspective. Leiden: MartinusNijhoff. http://dx.doi.org/10.1163/ej.9789004191150.i-205

Tierney, B. (1982). Religion, Law, and the Growth of Constitutional Thought 1150-1650. Cambridge: Cambridge University Press. http://dx.doi.org/10.1017/CBO9780511558627

Vile, M. J. C. (1967). Constitutionalism and the Separation of Powers. Oxford: Oxford University Press.

von Mohl, R. (1832). Die Polizei-Wissenschaftnach den Grundsatzen des Rechtstaates. Zweiteumgearbeitete Auflage. German Edition by British Library, Historical Print Editions (2011).

Weber, M. (1978). Economy and Society. Berkeley, CA: University of California Press.

Weingast, B. (1989). The Political Institutions of Representative Government: Legislatures. Journal of Institutional and Theoretical Economics, 145, 693-703. Reprinted In E. Furubotn, \& R. Richter (Eds.), The New Institutional Economics. Tübingen: J.C.B. Mokr (Paul Siebeck) and College Station: Texas A\&M Press, 1991.

White, W. D. (1992). Information and the Control of Agents. Journal of Economic Behavior and Organization, 18, $111-117$. http://dx.doi.org/10.1016/0167-2681(92)90056-H

World Bank (2012). Governance Project. http://info.worldbank.org/governance/wgi/

Wormuth, F. D. (1949). The Origins of Modern Constitutionalism. New York: Harper. 
Scientific Research Publishing (SCIRP) is one of the largest Open Access journal publishers. It is currently publishing more than 200 open access, online, peer-reviewed journals covering a wide range of academic disciplines. SCIRP serves the worldwide academic communities and contributes to the progress and application of science with its publication.

Other selected journals from SCIRP are listed as below. Submit your manuscript to us via either submit@scirp.org or Online Submission Portal.
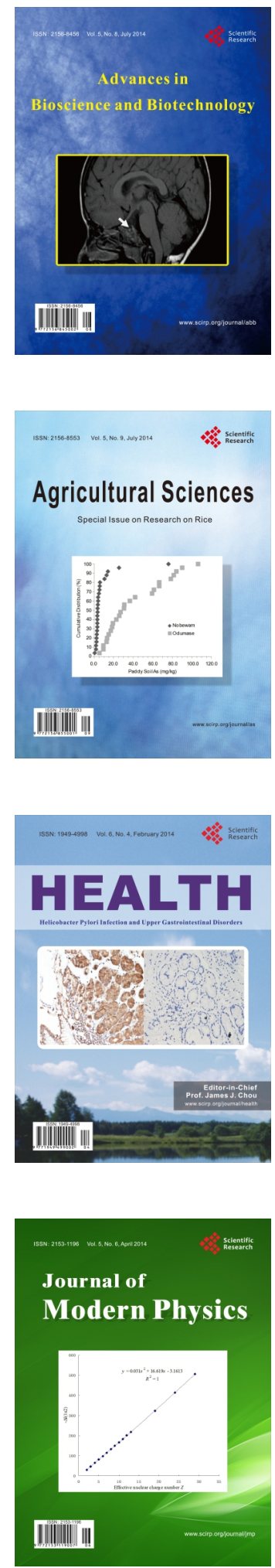
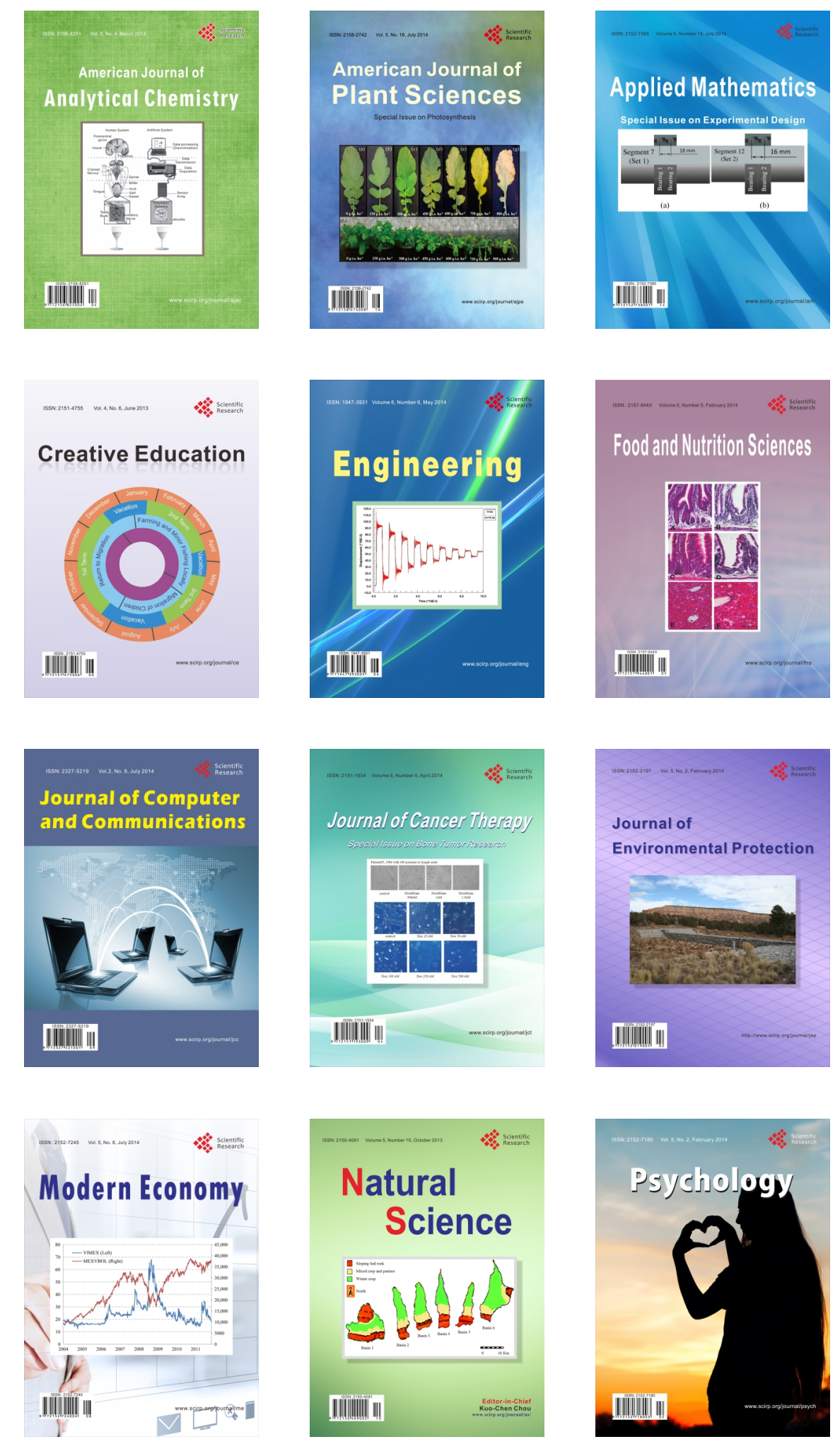